Firms' Technological Capabilities toward the Introduction of Industry 4.0: The Case of Supplier Firms in the Indonesian Automotive Industries

Tri Wisnuasih Pratiwi

Ministry of National Development Planning/Bappenas - Indonesia

Corresponding author. Email: triw.pratiwi@gmail.com

Submitted: 2020-12-16 | Accepted: 2021-04-26 | Published: 202 1-04-30

\begin{abstract}
This article examines changes in the technological capabilities of the supplier firms in the automotive sector after the introduction of Industry 4.0. The Industry 4.0 policy has recently been introduced to revive the manufacturing industry and promote competitiveness in the global market. Questionnaire data were collected from 32 supplier firms of the automotive component industry in Indonesia. The questionnaire was designed to measure variables, including production, investment, innovation, and linkage capabilities. The result shows that the Indonesian supplier firms, mainly large firms, are engaged in Industry 4.0, which affects their capabilities. Production capabilities have been improved among most firms, including large, small, and medium enterprises. There is an improvement in the volume of production and the quality of products. However, Indonesian small and medium firms acknowledged the limitation of investment and innovation capabilities. Compared with large firms, small and medium firms have limited resources that hinder them from investing in technology or human capital. During the introduction of advanced technologies, supplier firms' linkage relationship and their customers remain relatively stagnant. Moreover, in terms of linkages, in which the arrangement between assemblers and suppliers has been set, the automotive firms are highly independent.
\end{abstract}

Keywords: technological capabilities, industry 4.0, Indonesia automotive industry 


\title{
Firms' Technological Capabilities toward the Introduction of Industry 4.0: The Case of Supplier Firms in the Indonesian Automotive Industries
}

\author{
Tri Wisnuasih Pratiwi
}

\section{Introduction}

Recently, the Fourth Industrial Revolution, also known as the Industrial Revolution (IR) 4.0, has been a popular theme in many countries. IR 4.0 refers to Schwab (2017) as a revolutionary concept in which virtual and physical manufacturing systems communicate flexibly with each other. The concept of IR 4.0 was recognized by the German Trade and Investment (GTAI) organization at the World Economic Forum (2016) as a critical issue for changing work and production, mostly in the industrial sector. The disruptive stage of IR 4.0 initiates new technology drivers, ${ }^{1}$ such as the Internet of Things (IoT) (Atzori et al., 2010), smart factory system (Lee, 2015), cyber-physical systems (Hu et al., 2016), and Internet of Services (IoS) (Gao et al., 2011). These new technologies contribute to a system integration that increases productivity and innovation and intensifies industrial production (Park, 2018).

Regarding the newest technology, many scholars identify the cutting-edge IR 4.0 as a significant trigger to increase productivity, mainly concentrating in manufacturing sectors in the countries (Park, 2018; Schwab, 2017; Sniderman et al., 2016).

Nonetheless, despite the increase of Industry 4.0 attractiveness, there is an old and new discussion that the Industrial Revolution (at any stage) has a disruptive impact on the workforce and challenging firms as a whole. ${ }^{2}$ The introduction of Industry 4.0 will challenge the supply chain structure, from suppliers and manufacturers to customers. The recent discussion about assessing the micro-level capabilities is quite limited, mainly since Industry 4.0. At a micro level, disruptive technology affects firm performance, in which a firm might gain advantages or suffer losses. In the widely-known discussion, micro-levels cannot participate in an open market; because they were incapable of adapting to dynamic market conditions and establishing effective linkages with other stakeholders (Lall, 2001, pp. 14$17)$.

Notably, many small-medium firms in the Indonesian automotive industry have to strive with limited capacity and resources to deploy new technology. Furthermore, the local supplier firms in Indonesia typically were engaged in low-quality component products for which raw materials and essential parts were mostly imported from other countries. ${ }^{3}$ However, to achieve productivity and growth, micro-level firms need to innovate and upgrade their quality. The question about firms' capabilities has arisen, mainly in tackling the new policy of the introduction of Industry 4.0. Hence, the policy initiative of the introduction of technological advancement in Indonesia needed to assess whether the

\footnotetext{
${ }^{1}$ Industrial Revolution (IR) 4.0 and Industry 4.0 used interchangeably in the study.

${ }^{2}$ The discussion started to come to the surface based on the history of the First Industrial Revolution in England, the mass transition of new technology sparked workers' fears. The situation raised concerns about the effect of technological change on employment (Mckinsey, 2017).

${ }^{3}$ The auto parts raw material; likewise, steel and plastic still rely on imports from Japan and South Korea (Kemenperin, 2015).
} 
Industry 4.0 support principally to the micro-level helped them improve their capabilities or hinder them from competing in the market.

Then, technological capabilities would be the main determinant to describe how the microlevel accommodates their capacity to enter the innovation and competition stage. This paper examines changes in micro-level technological capabilities in the automotive sector after the introduction of Industry 4.0. In other words, this paper will explore to what extent the firms' capabilities improve or not by describing the situation before and after the implementation of advanced technologies.

\section{Review of Making Indonesia 4.0 Policy}

The establishment of the "Making Indonesia 4.0" policy was declared by the Government of Indonesia (GoI) in April 2018. This breakthrough initiative was expected to boost the industrial sector to reach more than $30 \%$ of GDP contribution by raising productivity and promoting innovation. In 2015 alone, the composition of GDP contribution from the manufacturing industry was $21.7 \%$. Accordingly, the manufacturing share would decline sharply and contribute around $6.3 \%$ by 2030 without intervention (policy) (Kearney \& Kemenperin RI, 2018). Thus, GoI launched the Making Indonesia 4.0 publicly to envision the country as a global top 10 economy by 2030 by regaining export advantage, raising the GDP share (10\% net export contribution to GDP), and increasing productivity through technological advancement (Kemenperin, 2018).

In the Making Indonesia 4.0 policy, there are five prioritizing sectors as the primary focus to accelerate productivity in the country, which are automotive, electronics, textiles and apparel, chemical, food, and beverage sectors. Therefore, the GoI selects those priority areas based on the extent of GDP contribution to the manufacturing industry and attractiveness of domestic market growth potential in Indonesia. Accordingly, the automotive industry is an attractive contributor to Indonesia's national economic growth (Rasiah et al., 2016). Also, the automotive industry has many opportunities as the second largest production capacity in the Southeast Asia region and the largest domestic market. ${ }^{4}$ After recovering from the 1998 Asian financial crisis, there was a swift growth in sales of motor vehicles and auto parts in the local market, whereas automotive production and sales in Indonesia dominated were by two-wheel (2W) (BPS, 2020). Furthermore, the trend of four wheels $(4 \mathrm{~W})$ vehicles is

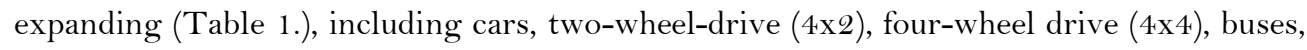
trucks, and Low-Cost Green Car (LCGC).

\footnotetext{
${ }^{4}$ According to the data from the Ministry of Industry Indonesia (2018), Indonesia's vehicle production and export capacity is in second place after Thailand.
} 
Table 1.: Vehicles Data Production 2015-2019

\begin{tabular}{l|lllll}
\multicolumn{1}{l}{ Vehicles } & $\mathbf{2 0 1 5}$ & $\mathbf{2 0 1 6}$ & $\mathbf{2 0 1 7}$ & $\mathbf{2 0 1 8}$ & $\mathbf{2 0 1 9}$ \\
\hline Cars & 61499 & 29644 & 30202 & 25807 & 32528 \\
Jeeps $4 x 2$ & 556078 & 663794 & 684828 & 744654 & 747124 \\
Jeeps $4 x 4$ & 29766 & 19378 & 19845 & 24132 & 20985 \\
Buses & 3873 & 4769 & 2500 & 3460 & 3275 \\
Trucks & 270462 & 205101 & 233219 & 284480 & 237907 \\
LCGC & 177102 & 255660 & 249834 & 261170 & 245029 \\
Sub Total & $\mathbf{1 0 9 8 7 8 0}$ & $\mathbf{1 1 7 8 3 4 6}$ & $\mathbf{1 2 2 0 4 2 8}$ & $\mathbf{1 3 4 3 7 0 3}$ & $\mathbf{1 2 8 6 8 4 8}$ \\
Motorcycles & 6708384 & 6215350 & 6320794 & 6383108 & 6487460 \\
Total & $\mathbf{7 8 0 7 1 6 4}$ & $\mathbf{8 5 7 2 0 4 2}$ & $\mathbf{8 7 6 1 6 5 0}$ & $\mathbf{9 0 7 0 5 1 4}$ & $\mathbf{9 0 6 1 1 5 6}$
\end{tabular}

Sources: BPS, 2020; Gaikindo, 2020.

Another notable attractiveness, the automotive industry mostly magnetizes foreign direct investment (FDI) from other countries, like Singapore and Japan. As stated by the Ministry of Industry of the Indonesian government (2018), FDI inflows for the automotive industry in Indonesia were from Singapore around 32\%, while Japan was the second-largest home country of FDI, approximately 19\% (Kemenperin, 2018). Figure 1. shows that the domestic car market's sales and production began to grow in 2009, whereas sales for car vehicles in 2012 alone reached over 1.2 million. Indeed, Indonesian automotive firms have to supply the vast domestic market's needs since Indonesia has become the fourth populous nation in the world. In the objectives of making the Indonesia 4.0 policy, automotive sectors aspired to enhance raw material and key component productions, improve productivity by adopting technology and infrastructures, align with global OEMs to boost export for specific vehicle types (Kemenperin, 2018).

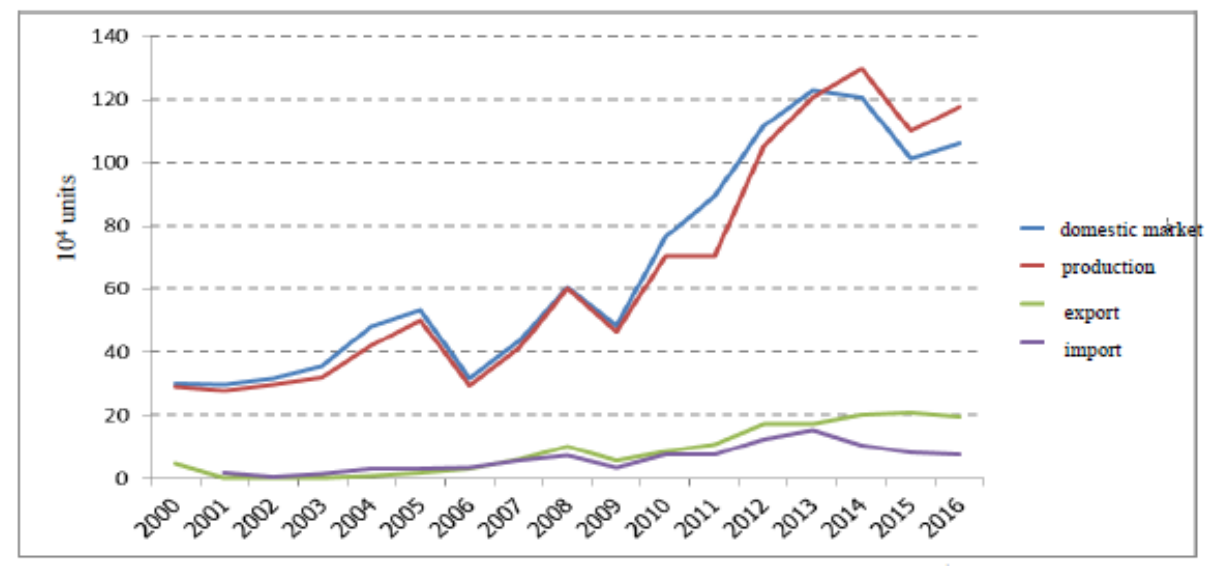

Figure 1.: Changes in automotive production, export, import, and sales in Indonesia 
Sources: Gaikindo, 2020; NRI, 2017

In the automotive sectors, this situation has led to intense competition in supplier firms' technological capabilities to produce sustainable products and services. Thus, to have a final decent quality product, the car producers must receive a good grade raw material and its component. In the end, the situation attracts many firms, especially supplier firms in Indonesia, to upgrade their capabilities, mainly to compete in technology absorption to produce better quality products and supply them to the assemblers or OEM. The discussion about Indonesian automotive industries, particularly supplier firms' capabilities, contributes to the construction of this study. Adopting advanced technologies 4.0, the automotive sectors, expected to accelerate its production processes, produce high-quality products, improve productivity by adopting technology and infrastructures, and align with global OEMs to boost export for specific vehicle types (Kemenperin, 2018).

\section{Defining Firms Technological Capabilities}

The theory of the firm's technological capabilities (FTC) mainly measures the production function of the firm (Amsden, 2001; Lall, 1992). Even though the firm has more understanding of its own technology and capacity, however, to improve its production function, firms need to import, learn, or duplicate technology from other advanced firms. Therefore, the nature of technological capabilities demands specific skills, including technical and managerial abilities, to manage and operate the technology. Thus, it is necessary to build and develop technological capabilities to boost productivity and have sustainable growth of the firms (Lall, 2001). The literature review of FTC primarily relates to the question of how a firm assimilates, acquires, adapts, and creates technology to compete and enter the global value chain (Ernst et al., 1998). The broad dimension of a firm's technological capabilities framework comprises production, investment, innovation, and linkage capabilities (Amsden, 2001; Lall, 1992).

Many studies have shown the lesson-learned in improving the technological capabilities at the macro and micro levels. Prior to that, the technology policies should be a highlight, not just how the country or a firm applied to the new technology (Industry 4.0). However, they mostly should focus on upgrading the firm's capability, especially to find the appropriate technology to improve their productivity. Given this context, the paper will concentrate on the introduction of Industry 4.0 in Indonesia and analysis its influence on the upgrading firm's technological capabilities. The research framework presented below shows the focus of the study. 


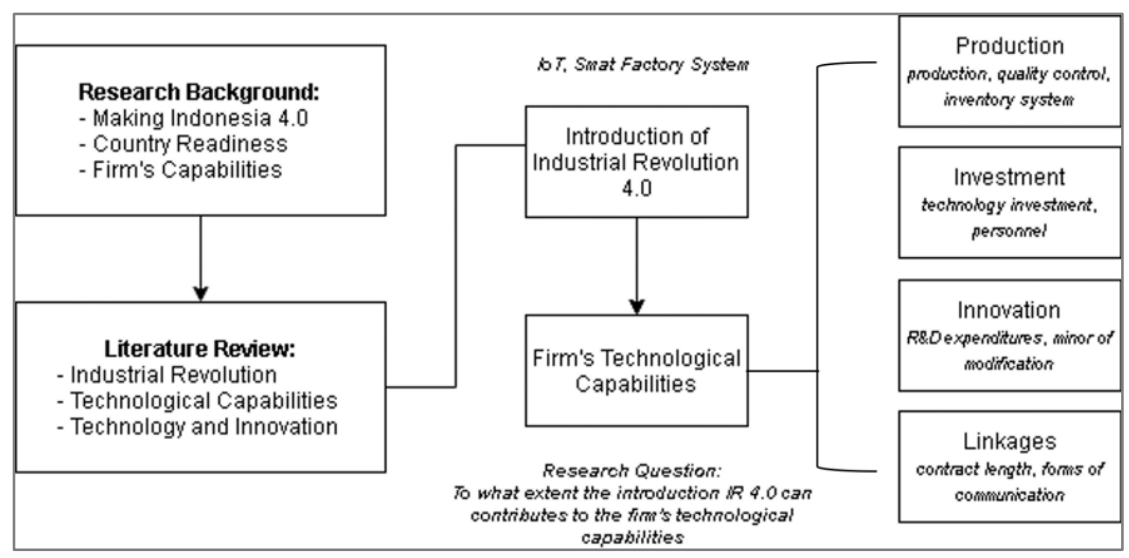

Figure 2.: Research Framework

Sources: Author's construction

This paper attempts to answer the questions concerning the relationship between the introduction of new technologies, capabilities, and specifically micro-level skills in the automotive supplier industries. The structure in measuring a firm's technological capabilities considered by (i) production capabilities, (ii) project-execution or investment capabilities, (iii) innovation capabilities, and (iv) linkage capabilities as an essential ability that has to be internalized in the firm (Amsden, 2001; Aswicahyono \& Kartika, 2010; Ernst et al., 1998; Lall, 1992; Vongpanitlerd, 1992). More specifically, in the subsequent chapters, the firm's capabilities in the four main elements are analyzed to see the implications before and after the introduction of Industry 4.0 in Indonesia.

This paper focuses on Indonesia, where manufacturing industries are mainly located on Java island, whereas economic activities and capital cities are located nearby Jabodetabek. Although the government enacted decentralization, ${ }^{5}$ the majority of $70 \%$ of the value-added has been created, primarily in greater Jakarta (including Jakarta, West Java, and Banten) and East Java (ADB-Bappenas, 2019). Massive infrastructure, such as road, port, and energy supply availability, supports the creation of manufacturing industries in those areas. Therefore, this paper focuses on the automotive industry located in greater Jakarta or called Jabodetabek. ${ }^{6}$ There are sixteen car manufacturers and nine motorcycle manufacturers located in Jabodetabek (Syah, 2019). Those manufacturers create linkages with many supplier firms and automatically lead to industrial clusters (Simmie \& Sennett, 1999). Thus, I chose Jabodetabek as the site of this paper, because of the concentration of supplier firms located close to or around the manufacturers in this area (see Figure 2.). The fieldwork involved a micro-level study that the unit of analysis is supplier firms. Then, supplier firms will be the survey participants of this paper. In the automotive industry in Indonesia, suppliers consist of Tier-1, Tier-2, and Tier-3 supplier firms. In brief, these three layers of supplier firms in Indonesia's automotive industries can be characterized as follows: Tier-1 suppliers supply their products to the assemblers (OEM), while Tier-2 suppliers provide

\footnotetext{
${ }^{5}$ Since 2000, decentralization enables other provinces in Indonesia to have the power to build wide-range responsibilities, including social system, infrastructure, manufacturing, and other economic sectors. Retrieved from https://www.adb.org/publications/government-decentralization-program-indonesia on May 7, 2020.

${ }_{6}^{6}$ Jabodetabek abbreviated for Jakarta, Bogor, Depok, Tangerang, and Bekasi, is a group of five-cities located close.
} 
their products to the Tier-1, and Tier 3 supplies to Tier 2 (Syah, 2019). In this paper, as the representative of typical firms in Indonesia, Tier-1 suppliers will be categorized as large firms while Tier- 2 and 3 as SMEs. ${ }^{7}$ The respondents in this paper are "senior managers" that know the whole procedural aspects of the firm. These senior managers include the owners, directors, and heads of the production unit in the firms.

\section{Result: Introduction of Industry 4.0 to Supplier Firms}

This study examined the introduction of Industry 4.0 to firms' technological capabilities by focusing on 32 suppliers of the Indonesian automobile industry. The category of large firms and SMEs and its technologies were classified to see its variation. These suppliers employ varying types of current technology, such as IoT, Robotics, and also conventional technology, such as CNC, CAD/CAM at their plants. In this section, I categorized two types of discussion: firms adopt Technology 4.0, and firms adopt conventional technology to see the changes after the Industry 4.0 policy introduced in 2018. There are 15 out of 32 supplier firms adopt Technology 4.0, including 12 large firms (Tier-1) and 3 SMEs (Tier-2 and Tier3), which will be discussed in the following with firms that adopt conventional technology (17 firms). This paper uses codes to indicate these firms. The type of conventional technologies would not be described in detail. Thus, large supplier firms (C3, C4, C14) stated they recognized and had adapted the recent technology particularly long before "Making Indonesia 4.0" policy was introduced in 2018 , while some others $(\mathrm{C} 1, \mathrm{C} 2, \mathrm{C} 10)$ started adopting the Technology 4.0 straightly in 2019 , one year after the policy was launched.

\subsection{Type of Technology in Supplier Firms}

Figure 3. indicates that there are 15 supplier firms applied to Technology 4.0, such as IoT, Robotics, RFID, AGV system, real-time inventory system, and GPS monitoring system, including three SMEs (C19, C29, C32). However, only 9 out of 15 firms responded to the exact year technology 4.0 applied in firms while the rest (6 out of 15 firms) did not answer in detail.

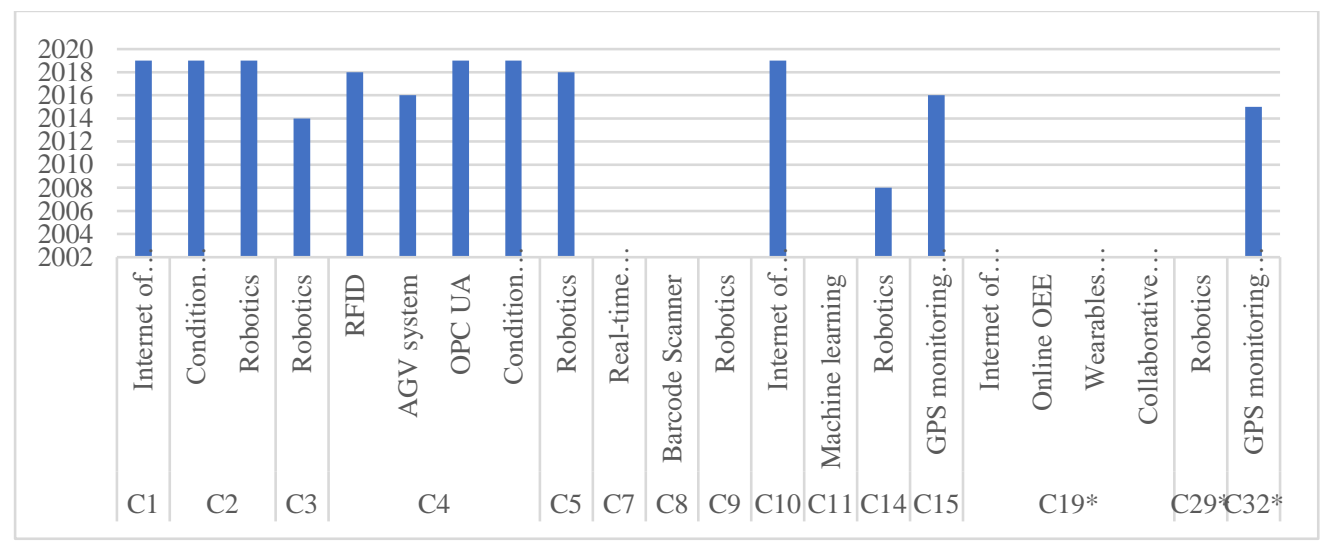

Figure 3: Technology 4.0 in the Firms

\footnotetext{
${ }^{7}$ Refer to the Ministerial Regulation of Industry Indonesia number 64 the year 2016, the classification of industrial businesses in Indonesia, mainly regarding workers' size and investment (Kemenperin, 2016).
} 
Sources: Questionnaire survey conducted in March 2020 by the author.

Notes:

a $\mathrm{n}=15$; consist of 12 large firms, 3 SMEs (*).

b Multiple answers were permitted in this question.

c 9 out of 15 firms responded when technology 4.0 adopted in the firms (which year).

d 6 out of 15 firms did not respond when technology 4.0 adopted in the firms (which year).

\subsection{Discussion: What Has Improved and What Has Not?}

The examination of production capabilities addresses the question of how well the supplier firms can improve the volume of production and control the quality of their products. Also, redesigning the inventory systems become crucial at the plants to improve the production processes more effectively and efficiently (Vongpanitlerd, 1992). The majority of firms acknowledged an increase in their outputs; firms that adopt Technology 4.0 (12 out of 15 firms) and conventional technology (12 out of 17 firms). On the other hand, the defect rates improvement was seen more among SMEs than large firms. Even though these SMEs employed standard technologies such as CNC, CAM, and PLC, the quality of their products is improved. The inventory system, including the efficiency of the tracking process and product delivery, benefits the firms that have more resources. Moreover, large firms have more techniques for inventory tracking system than SMEs and become one of the essential factors to improve the processes more effectively and efficiently in the firms.

Regarding investment capabilities, large and SME suppliers have different conditions in common, mainly in the amount of technology's investment. Large firms (C11, C12, C13, C16) invested more than 15 billion IDR (approx. US\$ 1 million), lead them to have more selection in setting up and expanding new technology. 6 out of 15 firms that adopt Technology 4.0 spend around 1-15 billion IDR (approx. US\$ 70,000 - 1 million). SME suppliers (9 out of 17 firms) who have limited budgets and access to technology, mostly spend less than 1 billion IDR (approx. US $\$ 70,000)$. The number of engineers and educational backgrounds requires a higher number and specification, mainly for firms that adopt technology 4.0. The majority of large firms have more bachelor degree graduates ( 11 out of 22 responses), while engineers' educational background among the SMEs is mostly 3 years of diploma (15 out of 20 responses).

Regarding innovation, supplier experienced minor modifications in the process of successful technological catching-up. The change in specific products such as automobile parts is rare. Nonetheless, to develop a product, even in making small changes in the design of their products, firms must accumulate technology, knowledge, and experience (Bell \& Pavitt, 1995). In other words, it may be possible for firms, which have better access to advanced technologies, to do innovation in the design and production activities. However, 7 out of 15 large firms and 6 out of 17 SMEs recognized minor modification in the products were made, less than three times a year. Apparently, some large firms claimed that they had modified the design of their products more than three times a year since they applied more technologies in their production unit such as Robotics, IoT, CNC, MES (C7 and C15).

With regard to the large firms' expenditure on R\&D, still, the expenditure is too small to bring about advanced development. Firms that adopt Technology 4.0 spent up to 15 billion 
IDR (approx. US\$ 1 million) for R\&D expenditures (C7, C9, C11, C14, C19). Then, a question arises as to how much budgets are needed to innovate. The optimal R\&D investment needs at least four times greater than actual spending (Jones \& Williams, 2000). However, the situation in each sector or industry is different. The Indonesian automotive industry, primarily supplier and manufacturers firms, focuses merely on car accessories and production processes as their innovation activities (Aswicahyono \& Kartika, 2010). Nonetheless, the status of their budget is linked to what the firms have to support their innovation activities. In the findings, the majority of these supplier firms claimed that they are engaged in innovation, focusing on the production process (8 out of 15 firms). Some firms mentioned the redesign line system (C26), new working instruction (C1), reorganize inventory processes $(\mathrm{C} 18)$ as their innovation initiatives.

Concerning the linkage capabilities, long-term written agreements are evidence of a relationship between customers and suppliers in the automotive industry. In theory, to control and coordinate among stakeholders, there is a need for the form of commitment and communication (Sako \& Helper, 1998). Moreover, this study found a fixed-term dedication between supplier firms and their customer. Additionally, the arrangement between assemblers and suppliers in the automotive sector is highly independent of each other (Veloso \& Soto, 2001). 7 out of 15 firms have more than ten years of relationships with the assemblers, while small-medium firms' interactions range from 5 to 10 years of contracts even before the adoption Technology 4.0. As C11 stated that the fixed-term contracts had been a long tradition in the country and associated with a higher level of trust or opportunism (Sako \& Helper, 1998). The forms of communication also determine the commitment between the customer and its suppliers. Given this context, communication forms between supplier firms and assemblers are constant, using interactive communication tools and regular visits as the main tools to share information and provide technical assistance. During the introduction of Industry 4.0, the form of communication has been restructured, as an integrated system is used between customers and large supplier firms.

\subsection{Conclusion}

This paper examines changes in the technological capabilities of the supplier firms in the automotive sector after the introduction of Industry 4.0. Recently, Industry 4.0 policy has been introduced to revive the manufacturing industry and promote competitiveness in the global market. Questionnaire data were collected from 32 supplier firms of the automotive component industry in Indonesia. The questionnaire was designed to measure variables, including production, investment, innovation, and linkage capabilities. The result shows that the Indonesian supplier firms, mainly large firms, are engaged in the Industry 4.0; and this engagement affects their capabilities. Production capabilities have been improved among a majority of the firms, including large, small and medium enterprises. There is an improvement in the volume of production and the quality of products. However, Indonesian small and medium firms acknowledged the limitation of investment and innovation capabilities. Accordingly, compared with large firms, small and medium firms have limited resources that hinder them from investing in technology or human capital. During the introduction of advanced technologies, the linkage relationship of supplier firms and their customers remain relatively stagnant. Moreover, in the terms of linkages, in which the 
arrangement between assemblers and suppliers has been set, the automotive firms are highly independent of each other.

The study also found that the Indonesian supplier firms are engaged in the Technology 4.0; and assessed how this engagement affects their capabilities. Production capabilities have improved at the majority of the firms, including SMEs. With regard to production capabilities, the types in technology adopted differ between large firms and SME suppliers. Thus, even the methods are not the same; both firms, including firms that adopt Technology 4.0 and conventional technology, improved the product outputs. There is an improvement in the volume of production and the quality of products. Nevertheless, Technology 4.0 is hard to apply at SMEs. By and large, to select the technology appropriate for their operation, it is necessary for the firms to look beyond its capacity and decide which technology can improve production more efficiently and effectively (Dahlman et al., 1987). Accordingly, SMEs under this study experienced the limitation of investment and innovation capabilities. Compared with large firms, SMEs have limited resources that hinder them from investing in technology or human capital. During the introduction of Technology 4.0, the linkage relationship between supplier firms and their customers remain constant. Even though the forms of communication has been restructured in a new platform, an integrated system that connects suppliers and its customers.

The introduction of Technology 4.0 may make a difference in the capabilities at the microlevel. The opportunity to choose Technology 4.0, particularly in the manufacturing sector, has expanded since the advantages have been widely spread (Schwab, 2016). Even though some firms have a close linkage with foreign firms, the inability to generate knowledge spillovers becomes an issue. Moreover, Indonesian supplier firms have limitations in investment and innovation capabilities. As a result, proper investment in the $\mathrm{R} \& \mathrm{D}$ sector becomes crucial to stimulate advanced learning, productivity, and innovation in Indonesia. Another implication is that technology policies should emphasize on how the firms learn to acquire their capabilities, rather than focus on how firm applied Industry 4.0. In other words, the policies mostly should focus on upgrading the firm's capability, including SMEs. As a result, new types of policies are needed to address developing firm capacities and to build networking among firms. At the national and strategic levels, programs sponsored by the triple-helix collaborations (government, universities, and private institutions) must be freely available to SMEs to accelerate the learning process of basic science and technology (Wang et al., 2010).

\section{References}

ADB-Bappenas. (2019). Policies to Support the Development of Indonesia's Manufacturing Sector during 2020-2024. Asian Development Bank. http://dx.doi.org/10.22617/TCS199910-2

Amsden, A. H. (2001). Industrializing Late. In The Rise of "The Rest". Challenges to the West from Late-Industrializing Economies (pp. 1-31). Oxford University Press.

Aswicahyono, H., \& Kartika, P. (2010). Production Linkages and Industrial Upgrading: Case Study of Indonesia's Automotive Industry. ERIA Research Project Report 2009-7-4, Jakarta: ERIA., 57-86. 
Atzori, L., Iera, A., \& Morabito, G. (2010). The Internet of Things: A survey. Computer Networks, 54(15), 2787-2805. https://doi.org/10.1016/j.comnet.2010.05.010

Bell, M., \& Pavitt, K. (1995). The Development of Technological Capabilities. In Trade, Technology, and International Competitiveness (pp. 69-102). The World Bank.

BPS. (2020). Statistik Indonesia. Statistical Tearbook of Indonesia 2020. Badan Pusat Statistik.

Dahlman, C. J., Ross-Larson, B., \& Westphal, L. E. (1987). Managing Technological Development: Lessons from the Newly Industrializing Countries. World Development, 15(6), 759-775. https://doi.org/10.1016/0305-750X(87)90058-1

Ernst, D., Mytelka, L., \& Ganiatsos, T. (1998). Technological capabilities in the context of export-led growth: A conceptual framework. In Technological Capabilities and Export Success in Asia (pp. 5-35). Routledge.

Gao, J., Yao, Y., Zhu, V. C. Y., Sun, L., \& Lin, L. (2011). Service-oriented manufacturing: A new product pattern and manufacturing paradigm. Journal of Intelligent Manufacturing, 22(3), 435-446. https://doi.org/10.1007/s10845-009-0301-y

Hu, Lu, Y., Vasilakos, A. V., Hao, Q., Ma, R., Patil, Y., Zhang, T., Lu, J., Li, X., \& Xiong, N. N. (2016). Robust Cyber-Physical Systems: Concept, models, and implementation. Future Generation Computer Systems, 56, 449-475. https://doi.org/10.1016/j.future.2015.06.006

Jones, C. I., \& Williams, J. C. (2000). Too Much of a Good Thing? The Economies of Investment in R\&D. Journal of Economic Growth, 5, 65-85.

Kearney, A. T., \& Kemenperin RI. (2018). Making Indonesia 4.0. Ministry of Industry Indonesia.

Kemenperin. (2015). Rencana Induk Pembangunan industri Nasional 2015-2035. Kementerian Perindustrian Indonesia.

Kemenperin. (2016). Peraturan Menteri Perindustrian Republik Indonesia Nomor 64 tahun 2016 tentang Besaran Jumlah Tenaga Kerja dan Nilai Investasi untuk Klasifikasi Usaha Industri. Ministerial Regulation Number 64/2016.

Kemenperin. (2018). Roadmap Implementasi Industry 4.0 di Indonesia. Kementerian Perindustrian Indonesia.

Lall, S. (1992). Technological Capabilities and Industrialization. World Development, 20(2), 165-186.

Lall, S. (2001). What "Competitiveness" is and Why it is Important. Introduction: Growing Concerns about Competitiveness. In Competitiveness, Technology and Skills (pp. 1-55). Edward Elgar Publishing, Inc.

Lee, J. (2015). Smart Factory Systems. Informatik-Spektrum, 38(3), 230-235. https://doi.org/10.1007/s00287-015-0891-z

Mckinsey. (2017). Jobs Lost, Jobs Gained: Workforce Transitions in a Time of Automation. Mckinsey \& Company.

Park, S.-C. (2018). The Fourth Industrial Revolution and Implications for Innovative Cluster Policies. AI E SOCIETY, 33(3), 433-445. https://doi.org/10.1007/sO0146017-0777-5

Rasiah, R., Shahrivar, R. B., \& Amin, A. S. (2016). Host-site Support, Foreign Ownership, Regional Linkages and Technological Capabilities: Evidence from Automotive Firms in Indonesia. Asia Pacific Business Review, 22(1), 38-47. https://doi.org/10.1080/13602381.2014.990207 
Sako, M., \& Helper, S. (1998). Determinants of Trust in Supplier Relations: Evidence from the Automotive Industry in Japan and the United States. Journal of Economic Behavior E' Organization, 34(3), 387-417. https://doi.org/10.1016/So167-2681(97)00082-6

Schwab, K. (2016). The Future of Jobs: Employment, Skills and Workforce Strategy for the Fourth Industrial Revolution. World Economic Forum.

Schwab, K. (2017). The Fourth Industrial Revolution. In The Fourth Industrial Revolution (p. 192). Crown.

Simmie, J., \& Sennett, J. (1999). Innovative Clusters: Global or Local Linkages? National Institute Economic Review, $170(1), \quad 87-98$. https://doi.org/doi:10.1177/002795019917000112

Sniderman, B., Mahto, M., \& Cotteleer, Mark. J. (2016). Industry 4.0 and Manufacturing Ecosystems: Exploring the World Connected Enterprises. Deloitte University Press.

Syah, D. O. (2019). Identifying Vertical Partnership among Automotive Component Companies: Empirical Evidence from Automotive Industry in Jabodetabek, Indonesia. Journal of Economic Structures, 8(1). https://doi.org/10.1 186/s40008-019-0149-Z

Veloso, F. M., \& Soto, J. M. (2001). Incentives, Infrastructure and Institutions: Perspectives on Industrialization and Technical Change in Late-Developing Nations. Elsevier Science Inc., 23.

Vongpanitlerd, S. (1992). The Development of Thailand's Technological Capability in Industry. The Thailand Development Research Institute.

Wang, Wang, Y., \& Horng, R. (2010). Learning and Innovation in Small and Medium Enterprises. Industrial Management छे Data Systems, 110(2), 175-192. https://doi.org/10.1 108/02635571011020296 